\title{
Nutrient Management in Different Rice (Oryza sativa L.) Establishment Methods under Black Clay Soils of Tungabhadra Command
}

\author{
B. G. Masthana Reddy*, K. Mahantashivayogayya, Sujay Hurali and S. B. Gowdar
}

\author{
All India Co-ordinated Rice Improvement Programme, Agricultural Research Station, \\ Gangavathi-583 227, University of Agricultural Sciences, \\ Raichur, Karnataka (India)
}

*Corresponding author

\section{A B S T R A C T}

Field experiment was conducted at Agricultural Research Station, Gangavathi, Karnataka during the rainy season of 2015 and 2016 to evaluate nutrient practices

Keywords

Nutrient

management, LCC,

Dry direct seeded

rice

Article Info

Accepted:

18 May 2020

Available Online:

10 June 2020 for different rice establishment methods in comparison with puddle transplanting with recommended nutrient practice. Three establishment methods as main treatments and five nutrient practices as sub treatments were tried in split-plot design with three replications. Among establishment methods puddle transplanting recorded higher grain yield and among nutrient practices application of 200:100:100 kg N, $\mathrm{P}_{2} \mathrm{O}_{5} \& \mathrm{~K}_{2} \mathrm{O} / \mathrm{ha}, 150 \% \mathrm{RDF}$ and LCC based $\mathrm{N}$ application resulted in higher grain yields. The interaction revealed that a combination of puddle transplanting with either 200:100:100 kg N, $\mathrm{P}_{2} \mathrm{O}_{5} \& \mathrm{~K}_{2} \mathrm{O} / \mathrm{ha}$ or $150 \% \mathrm{RDF}$ and wet direct seeding with LCC based $\mathrm{N}$ management proved superior to puddle transplanting with recommended nutrient practice. However, LCC based $\mathrm{N}$ application in addition to maintaining on par yield with location specific practice also resulted in $31.5,25$ and $25 \%$ saving in $\mathrm{N}, \mathrm{P}$ and $\mathrm{K}$ respectively and $10 \%$ saving in $\mathrm{N}$ against recommended practice and can be adopted by the farmers.

\section{Introduction}

Rice is an important food crop of India, grown over an area of 43.44 mha with a production of $112.4 \mathrm{mt}$ and with a productivity of $2.7 \mathrm{t} / \mathrm{ha}$ (Anon 2016). In order to feed the growing population India need to produce $130 \mathrm{mt}$ of rice by the year 2030 according to projections by Indian Institute of Rice
Research, Hyderabad. Rice is grown under different establishment methods under various agro ecological conditions. In irrigated low land system it is traditionally established by manual transplanting with continuous ponding of water in the field. Due to non availability and high cost of labour, urbanization, mechanization and shortage of water availability a shift in the planting 
methods has been observed in recent years in many farmers fields and farmers are adopting many methods of establishment like mechanical transplanting, dry direct seeding and broadcasting of seeds on unpuddle soils. Though lot of work on nutrient management practices in transplanted rice has been carried out in the past, such work on other methods is very much lacking. Hence in the present investigation an attempt was made to evaluate different nutrient management practices for different establishment methods in comparison with traditional transplanting.

\section{Materials and Methods}

Field experiment was conducted on black clay soil during the rainy season of 2015 and 2016 at the Agricultural Research Station, Gangavati, coming under Tungabadra command of Karnataka. The soil of the experimental site was medium deep black clay in texture, neutral to alkaline in reaction (pH 8.1 to 8.3) and low in electrical conductivity $(0.50$ to $0.75 \mathrm{dS} / \mathrm{m})$. The soil was low in alkaline $\mathrm{KMnO}_{4}-\mathrm{N}\left(210 \mathrm{~kg} \mathrm{ha}^{-1}\right)$, high in Olsen's- $\mathrm{P}_{2} \mathrm{O}_{5}\left(74.5 \mathrm{~kg} \mathrm{ha}^{-1}\right)$ and high in $\mathrm{NH}_{4} \mathrm{OAc}$ extractable $\mathrm{K}_{2} \mathrm{O}\left(410 \mathrm{~kg} \mathrm{ha}^{-1}\right)$ in the surface $0-20 \mathrm{~cm}$ depth. The treatments consisted of three establishment methods viz., $\mathrm{M}_{1}$ : normal manual transplanting, $\mathrm{M}_{2}$ : wet direct seeding on puddle soil through drum seeding and $\mathrm{M}_{3}$ : dry direct seeding on un puddle soil as main plot treatments and five nutrient practices viz., $\mathrm{S}_{1}$ : $100 \%$ recommended $\mathrm{NPK}\left(150: 75: 75 \mathrm{~kg} \mathrm{~N}, \mathrm{P}_{2} \mathrm{O}_{5}\right.$ and $\mathrm{K}_{2} \mathrm{O} / \mathrm{ha}$ ), $\mathrm{S}_{2}: 75 \%$ inorganic $+25 \%$ organic on $\mathrm{N}$ equivalent basis of recommended NPK, $S_{3}: 150 \%$ of recommended NPK, $S_{4}$ : LCC based $\mathrm{N}$ application with recommended $\mathrm{P}$ and $\mathrm{K}$ and $\mathrm{S}_{5}$ : Location specific NPK (200:100:100 kg N, $\mathrm{P}_{2} \mathrm{O}_{5}$ and $\mathrm{K}_{2} \mathrm{O} / \mathrm{ha}$ ) were tried in split-plot design with three replications. Gangavathi sona (GGV-05-01) a medium duration rice variety maturing in 135 days was used. Direct seeding was done on $12^{\text {th }}$ August and $4^{\text {th }}$ August during 2015 and 2016 respectively. While transplanting was done on $11^{\text {th }}$ September and $3^{\text {rd }}$ September during 2015 and 2016 respectively. In the case of transplanting 30 days aged seedlings (at a seed rate of $62.5 \mathrm{~kg} / \mathrm{ha}$ ) were transplanted at $20 \times 10 \mathrm{~cm}$ spacing. While sprouted seeds at the rate of $45 \mathrm{~kg} / \mathrm{ha}$ were sown using a drum seeder in wet direct seeding on puddle soil and in the case of dry direct seeding seeds were sown at $22.5 \mathrm{~cm}$ spacing using a seed rate of $30 \mathrm{~kg} / \mathrm{ha}$. Recommended herbicides and need based plant protection measures were followed. Observations on grain yield and yield parameters were recorded and economics worked out.

\section{Results and Discussion}

\section{Effect on grain yield}

Among the establishment methods puddle transplanting recorded significantly higher grain yield during both years and in the mean data $(57.58,44.82$ and $50.93 \mathrm{q} / \mathrm{ha}$ respectively during 2015, 2016 and in the mean) as compared to wet seeding and dry direct seeding. The treatment recorded 11.1 and 14.2 $\%$ higher grain yield respectively over direct wet seeding and direct dry seeding. Among the nutrient practices $150 \%$ NPK and location specific NPK (200:100:100 kg N, $\mathrm{P}_{2} \mathrm{O}_{5}$ and $\mathrm{K}_{2} \mathrm{O} /$ ha) recorded significantly higher grain yield of 54.18 and $54.02 \mathrm{q} /$ ha respectively than recommended dose of 150:75:75 $\mathrm{kg} \mathrm{N}, \mathrm{P}_{2} \mathrm{O}_{5}$ and $\mathrm{K}_{2} \mathrm{O} / \mathrm{ha} \quad(49.29 \mathrm{q} / \mathrm{ha})$ during 2015.However, during 2016 LCC based NPK application and $150 \% \mathrm{RDF}$ recorded significantly higher grain yield of 46.64 and $45.97 \mathrm{q} / \mathrm{ha}$ than recommended dose. The two year mean data revealed that application of 200:100:100 kg N, $\mathrm{P}_{2} \mathrm{O}_{5}$ and $\mathrm{K}_{2} \mathrm{O} /$ ha recorded 9.6\% higher grain yield than recommended NPK which however remained on par with $150 \%$ NPK and LCC based N application. The interaction effect revealed that a 
combination of puddle transplanting $\mathrm{X}$ 200:100:100 kg N, $\mathrm{P}_{2} \mathrm{O}_{5}$ and $\mathrm{K}_{2} \mathrm{O} / \mathrm{ha}\left(\mathrm{M}_{1} \mathrm{~S}_{5}\right)$ recorded significantly higher grain yield of 61.81 and $52.17 \mathrm{q} / \mathrm{ha}$ respectively during 2015 and 2016 which however remained on par with puddle transplanting $\mathrm{x} 150 \% \mathrm{RDF}$ and puddle transplanting $\mathrm{x}$ LCC based $\mathrm{N}$ application. Earlier Srinivasagam Krishnakumar and Stefen Haefele (2013), Shantappa Duttarganvi et al., (2014), Ahmad Ali et al., (2015), Ashrabani Moharana et al., (2017), Tauseef A Bhatt et al., (2017) and Yogendra et al., (2017) reported higher grain yield of rice with less $\mathrm{N}$ application in the case of LCC based $\mathrm{N}$ application as compared to blanket application. The mean interaction was non significant.

\section{Savings in NPK}

The different nutrient practices revealed that LCC based NPK application accounted for 135:75:75 $\mathrm{kg} \mathrm{N}, \mathrm{P}_{2} \mathrm{O}_{5}$ and $\mathrm{K}_{2} \mathrm{O} / \mathrm{ha}$ which resulted in 31.5,25 and $25 \%$ saving in $\mathrm{N}, \mathrm{P}$ and $\mathrm{K}$ respectively as compared to location specific NPK (200:100:100 $\mathrm{kg} \mathrm{N}, \mathrm{P}_{2} \mathrm{O}_{5}$ and $\mathrm{K}_{2} \mathrm{O} / \mathrm{ha}$ ) and $10 \%$ saving in $\mathrm{N}$ against recommended practice (150:75:75 $\mathrm{kg} \mathrm{N}, \mathrm{P}_{2} \mathrm{O}_{5}$ and $\mathrm{K}_{2} \mathrm{O} / \mathrm{ha}$ ) besides remaining on par in grain yield with these treatments. Indranil Das and Narayanachandra sahu (2015) Reported that LCC based applications reduced the excessive $\mathrm{N}$ application in rice besides recording higher grain yield in rice.

In rice the grain yield is mainly determined by a combination of the number of panicles per square meter (sqm), panicle weight, number of filled grain per panicle and test weight. In the present study the panicle per square meter were significantly higher in the case of dry direct seeding as compared to other methods. Among the nutrient practices the application of 150\%RDF, 200:100:100 kg N, $\mathrm{P}_{2} \mathrm{O}_{5}$ and $\mathrm{K}_{2} \mathrm{O} /$ ha and LCC based $\mathrm{N}$ application recorded significantly higher number of panicles than recommended practice and contributed to higher grain yield in these treatments. On the other hand the panicle weight and the number grains per panicle were significantly higher in the case of puddle transplanting than other methods and in turn contributed to higher grain yield. There was no significant difference in panicle weight among nutrient practices. Among the nutrient practices application of 200:100:100 kg N, $\mathrm{P}_{2} \mathrm{O}_{5}$ and $\mathrm{K}_{2} \mathrm{O} /$ ha followed by $150 \% \mathrm{RDF}$ recorded more grains per panicle and contributed for higher yield. The interaction effect for panicle number and weight was non significant.

\section{Economics}

The economics (Table 2) revealed that puddle transplanting recorded 11.43 and $14.93 \%$ higher mean net returns over wet and dry direct seeding respectively. Among the nutrient practices, application of 200:100:100 $\mathrm{kg} \mathrm{N}, \mathrm{P}_{2} \mathrm{O}_{5}$ and $\mathrm{K}_{2} \mathrm{O} /$ ha recorded higher net returns during 2015. However, LCC based $\mathrm{N}$ application proved superior during 2016 and in the mean data representing 24 and $17 \%$ higher net returns than recommended practice. The interaction revealed that a combination of puddle transplanting $\mathrm{x}$ 200:100:100 kg N, $\mathrm{P}_{2} \mathrm{O}_{5}$ and $\mathrm{K}_{2} \mathrm{O} /$ ha recorded higher net returns during 2015 which however remained on par with puddle transplanting $\mathrm{x}$ $150 \% \mathrm{RDF}$ and puddle transplanting $\mathrm{x}$ LCC based $\mathrm{N}$ application. However, during 2016 wet direct seeding $\mathrm{x}$ LCC based $\mathrm{N}$ application recorded higher net returns than recommended practice and $150 \%$ RDF. The mean data revealed that puddle transplanting $\mathrm{x}$ 200:100:100 kg $\mathrm{N}, \mathrm{P}_{2} \mathrm{O}_{5}$ and $\mathrm{K}_{2} \mathrm{O} / \mathrm{ha}$ recorded higher net returns but remained on par with puddle transplanting $\mathrm{x} 150 \% \mathrm{RDF}$ and direct wet seeding $\mathrm{x}$ LCC based $\mathrm{N}$ application. The results are in line with ${ }^{[9]}$ who reported higher additional income due to LCC based $\mathrm{N}$ application in rice. 
Among the establishment methods the BC ratio was significant only during 2016 with direct wet seeding recording higher $\mathrm{BC}$ ratio of 2.11. Among nutrient practices LCC based $\mathrm{N}$ application recorded higher $\mathrm{BC}$ ratio during both years and in the mean indicating economic profitability of LCC based $\mathrm{N}$ application. The interaction revealed that $\mathrm{BC}$ ratio was non significant during 2015.

Table.1 Grain yield and yield parameters as influenced by establishment methods and nutrient practices in rice

\begin{tabular}{|c|c|c|c|c|c|c|}
\hline \multirow{2}{*}{$\begin{array}{l}\text { Establishment } \\
\text { methods }\end{array}$} & \multicolumn{3}{|c|}{ Grain yield(q/ha) } & \multirow{2}{*}{$\begin{array}{c}\begin{array}{c}\text { Panicles } \\
\text { /sqm }\end{array} \\
\text { Mean }\end{array}$} & \multirow{2}{*}{$\begin{array}{c}\text { Panicle } \\
\text { weight }(g) \\
\text { Mean }\end{array}$} & \multirow{2}{*}{$\begin{array}{c}\text { Grains/ } \\
\text { panicle } \\
\text { Mean }\end{array}$} \\
\hline & 2015 & 2016 & Mean & & & \\
\hline M1 & 57.58 & 44.28 & 50.93 & 393 & 2.74 & 165.2 \\
\hline M2 & 48.68 & 41.46 & 45.27 & 401 & 2.57 & 150.3 \\
\hline M3 & 49.79 & 40.26 & 43.70 & 445 & 2.32 & 137.8 \\
\hline SEm & 1.25 & 0.65 & 1.20 & 7.50 & 0.06 & 3.43 \\
\hline $\mathrm{CD}(\mathrm{p}=0.05)$ & 5.03 & 2.55 & 4.70 & 29.6 & 0.24 & 13.48 \\
\hline \multicolumn{7}{|l|}{$\begin{array}{l}\text { Nutrient } \\
\text { practices }\end{array}$} \\
\hline S1 & 49.29 & 40.13 & 44.71 & 380 & 2.48 & 147.8 \\
\hline S2 & 49.74 & 32.36 & 41.38 & 410 & 2.53 & 145.7 \\
\hline S3 & 54.18 & 45.97 & 48.96 & 432 & 2.56 & 158.3 \\
\hline S4 & 52.88 & 46.64 & 48.65 & 417 & 2.51 & 142.00 \\
\hline S5 & 54.02 & 44.91 & 49.47 & 422 & 2.62 & 161.7 \\
\hline SEm & 0.78 & 1.06 & 1.04 & 11.4 & 0.05 & 2.85 \\
\hline $\mathrm{CD}(\mathrm{p}=0.05)$ & 2.29 & 3.09 & 3.02 & 33.2 & NS & 8.73 \\
\hline \multicolumn{7}{|l|}{ Interaction } \\
\hline M1S1 & 55.67 & 43.02 & 49.34 & 373 & 2.81 & 157.3 \\
\hline M1S2 & 53.10 & 32.92 & 43.01 & 377 & 2.60 & 172.7 \\
\hline M1S3 & 60.84 & 47.42 & 54.13 & 390 & 2.73 & 176.3 \\
\hline M1S4 & 56.70 & 47.50 & 52.10 & 422 & 2.57 & 148.7 \\
\hline M1S5 & 61.81 & 52.17 & 56.99 & 395 & 2.98 & 171.0 \\
\hline M2S1 & 43.48 & 36.72 & 40.10 & 373 & 2.48 & 145.0 \\
\hline M2S2 & 50.67 & 33.47 & 42.07 & 362 & 2.61 & 147.0 \\
\hline M2S3 & 51.57 & 43.77 & 47.67 & 440 & 2.64 & 156.3 \\
\hline M2S4 & 48.80 & 49.52 & 49.16 & 391 & 2.53 & 133.3 \\
\hline M2S5 & 48.87 & 43.83 & 46.35 & 371 & 2.57 & 169.7 \\
\hline M3S1 & 48.71 & 40.65 & 44.68 & 395 & 2.17 & 141.3 \\
\hline M3S2 & 45.43 & 30.70 & 38.06 & 425 & 2.37 & 117.3 \\
\hline M3S3 & 50.12 & 46.72 & 48.42 & 466 & 2.31 & 142.3 \\
\hline M3S4 & 53.33 & 44.52 & 48.93 & 438 & 2.43 & 144.0 \\
\hline M3S5 & 51.39 & 38.72 & 45.05 & 498 & 2.30 & 144.3 \\
\hline SEm & 1.76 & 1.76 & 2.00 & 19.2 & 0.09 & 5.59 \\
\hline $\mathrm{CD}(\mathrm{p}=\mathbf{0 . 0 5})$ & 5.15 & 5.14 & NS & NS & NS & 16.34 \\
\hline
\end{tabular}


Table.2 Economics of rice as influenced by establishment methods and nutrient practices

\begin{tabular}{|l|c|c|c|c|c|c|}
\hline & \multicolumn{3}{|c}{ Net returns(Rs/ha) } & \multicolumn{3}{c|}{ Benefit-cost ratio } \\
\hline Establishment & 2015 & 2016 & Mean & 2015 & 2016 & Mean \\
\hline methods & & & & & & \\
\hline M1 & 75276 & 49806 & 62541 & 2.52 & 2.00 & 2.26 \\
\hline M2 & 61969 & 48816 & 55392 & 2.41 & 2.11 & 2.26 \\
\hline M3 & 62149 & 44257 & 53203 & 2.41 & 1.95 & 2.15 \\
\hline CEm & 2716 & 1381 & 1661 & 0.05 & 0.03 & 0.05 \\
\hline Nutrient & 10665 & NS & 6521 & NS & 0.11 & NS \\
\hline practices & & & & & & \\
\hline S1 & 62068 & 44731 & 53400 & 2.36 & 1.98 & 2.17 \\
\hline S2 & 60705 & 25414 & 43060 & 2.39 & 1.54 & 1.91 \\
\hline S3 & 69197 & 54807 & 62002 & 2.42 & 2.13 & 2.27 \\
\hline S4 & 69903 & 59277 & 64590 & 2.55 & 2.32 & 2.44 \\
\hline S5 & 70449 & 53901 & 62175 & 2.50 & 2.15 & 2.32 \\
\hline SEm & 1681 & 2316 & 1709 & 0.05 & 0.05 & 0.04 \\
\hline CD(p=0.05) & 4908 & 6762 & 4989 & NS & 0.15 & 0.11 \\
\hline Interaction & & & & & & \\
\hline M1S1 & 72845 & 48735 & 60790 & 2.51 & 2.01 & 2.26 \\
\hline M1S2 & 64717 & 24052 & 44385 & 2.28 & 1.48 & 1.88 \\
\hline M1S3 & 80375 & 54770 & 67572 & 2.57 & 2.06 & 2.31 \\
\hline M1S4 & 74564 & 54729 & 64647 & 2.55 & 2.14 & 2.34 \\
\hline M1S5 & 83880 & 66745 & 75312 & 2.69 & 2.34 & 2.51 \\
\hline M2S1 & 52224 & 39446 & 45835 & 2.22 & 1.92 & 2.07 \\
\hline M2S2 & 65380 & 30250 & 47815 & 2.46 & 1.67 & 2.06 \\
\hline M2S3 & 66199 & 52301 & 59250 & 2.44 & 2.14 & 2.29 \\
\hline M2S4 & 64982 & 67796 & 66389 & 2.50 & 2.60 & 2.55 \\
\hline M2S5 & 62296 & 54286 & 58291 & 2.41 & 2.23 & 2.32 \\
\hline M3S1 & 61136 & 46012 & 53574 & 2.36 & 2.02 & 2.19 \\
\hline M3S2 & 52019 & 21942 & 36981 & 2.10 & 1.46 & 1.78 \\
\hline M3S3 & 61016 & 57353 & 59184 & 2.26 & 2.18 & 2.22 \\
\hline M3S4 & 71399 & 55307 & 63353 & 2.59 & 2.23 & 2.41 \\
\hline M3S5 & 65173 & 40673 & 52923 & 2.40 & 1.87 & 2.14 \\
\hline SEm & 3763 & 3845 & 3125 & 0.10 & 0.08 & 0.07 \\
\hline CD (p=0.05) & 10985 & 11224 & 9123 & NS & 0.24 & 2.00 \\
\hline & & & & & & \\
\hline
\end{tabular}

However during 2016 and in the mean data a combination of wet direct seeding $\mathrm{x}$ LCC based $\mathrm{N}$ application recorded higher $\mathrm{BC}$ ratio of 2.6 and 2.55 respectively and proved significantly superior to puddle transplanting $\mathrm{x}$ recommended practice and puddle transplanting x 150\%RDF.

The two year data indicated that puddle transplanting in combination with either location specific recommendation of 200:100:100 $\mathrm{kg} \mathrm{N}, \mathrm{P}_{2} \mathrm{O}_{5}$ and $\mathrm{K}_{2} \mathrm{O} / \mathrm{ha}$ or 
$150 \%$ RDF or LCC based $\mathrm{N}$ application proved superior than puddle transplanting $\mathrm{X}$ recommended practice in terms of grain yield. However based on economic analysis of net returns and $\mathrm{BC}$ ratio it can be concluded that puddle transplanting in combination with either 200:100:100 kg N, $\mathrm{P}_{2} \mathrm{O}_{5}$ and $\mathrm{K}_{2} \mathrm{O} / \mathrm{ha}$ or $150 \% \mathrm{RDF}$ and direct wet seeding with LCC based $\mathrm{N}$ application performed better and can be recommended for farmers adoption.

\section{References}

Ali, Ahmad Ali, Harmith singh THIND, Sandeep Sharma and Yadvinder Singh. 2015. Site specific nitrogen management in dry direct seeded rice using chlorophyll meter and Leaf colour chart. Pedosphere 25(1):72-81.

Anonymous, Agricultural statistics at a glance 2016. GOI, Ministry of Agriculture and farmers welfare, Dept of Agriculture, Co-operation and farmers welfare, Directorate of Economics and Statistics

Ashrabani Moharana, Gulati J M L and Jena S N. 2017. Effect of LCC based nitrogen application on growth and yield of rice varieties during dry season. Indian Journal of Agriculture Research 51(1): 49-53.

Indranil Das and Narayana Chandra sahu. 2015. Nitrogen management by using
Leaf Colour Chart in kharif rice in alluvial soils of West Bengal. Journal of Krishivigyan, 3(2):69-72.

Shantappa Duttarganvi, Channabavasanna, A.S, Satyanarayana Rao and Halepyati, A S.2014. Effect of LCC and SPAD based nitrogen management on growth and yield of low land rice. The Bioscan 9(2):663665

Srinivasagam Krishnakumar and Stefen Haefele. 2013. Integrated nutrient management and LCC based Nitrogen management on soil fertility and yield of rice. Scientific Research and Essays 8(41):2059-2067.

Tauseef A Bhat, Kotru R, Akhil Verma, Monzoor A Ganai Latie, Latief A, Dar and Nazeer A and Teli. 2017. Leaf colour chart based $\mathrm{N}$ management for yield, nutrient uptake and yield of rice genotypes. International Journal of current microbiology and applied Sciences 6(9): 3531-3538.

Yogendra N. D, Kumara B.H, Chandrashekar N, Prakash N B, Anantha M. S and Shashidar, H. E. 2017. Real time nitrogen management in aerobic rice by adopting leaf colour chart (LCC) as influenced by Silicon. Journal of plant nutrition 40(9): 1277-1286.

\section{How to cite this article:}

Masthana Reddy, B. G., K. Mahantashivayogayya, Sujay Hurali and Gowdar, S. B. 2020. Nutrient Management in Different Rice (Oryza sativa L.) Establishment Methods under Black Clay Soils of Tungabhadra Command. Int.J.Curr.Microbiol.App.Sci. 9(06): 1651-1656. doi: https://doi.org/10.20546/ijcmas.2020.906.204 